\title{
Dendritic cells inhibit myeloid-derived suppressor cells infiltration and function in mouse B16 melanoma microenvironment
}

\author{
Siyuan Xia*, Jun Wei, Jingya Wang, Liqing Zhao, Zhinan Yin \\ From Society for Immunotherapy of Cancer 28th Annual Meeting \\ National Harbor, MD, USA. 8-10 November 2013
}

Roles of dendritic cells (DCs) in tumor immune responses have been reported to be very complex. It has been shown that in some tumor types, dendritic cells play an protective role by activating anti-tumor cells, while in other tumor types, they accelated tumor growth by inducing immune suppressive cells. Myeloid-derived suppressor cells (MDSCs) have also been proved to take part in immunoregulatory network in tumor microenvironment. Recently MDSCs have been found to impair the quality of DCs vaccine and promote Treg function in some tumors. However, whether and how DCs influence on MDSCs in tumor remain unclear. Thus we used CD11c-DTR mice to built a three week long DCs depletion model to find out their effect on MDSCs. DCs depletion accelated tumor growth. After three weeks, we isolated tumor infiltrating lymphocytes and analysed MDSCs and relative lymphocytes by flow cytometry. We found that depletion of CD11c+ DCs in mice B16 melanoma model led to MDSCs percentage increased in tumor microenvironment. In addition, $\mathrm{CD} 4+$ and $\mathrm{CD} 8+\mathrm{T}$ cells produced less interferon-gamma and regulatory $\mathrm{T}$ cell (Treg) percentage increased. Thus, our results suggested that in cancer immunotherapy, DCs may inhibit MDSCs infiltration into tumor site and their function on $\mathrm{T}$ cells.

Published: 7 November 2013

doi:10.1186/2051-1426-1-S1-P195

Cite this article as: Xia et al:: Dendritic cells inhibit myeloid-derived suppressor cells infiltration and function in mouse B16 melanoma microenvironment. Journal for ImmunoTherapy of Cancer 2013

1(Suppl 1):P195.

State Key Laboratory of Medicinal Chemical Biology, College of Life Sciences, Nankai University, Tianjin, China

(0) 2013 Xia et al; licensee BioMed Central Ltd. This is an Open Access article distributed under the terms of the Creative Commons Attribution License (http://creativecommons.org/licenses/by/2.0), which permits unrestricted use, distribution, and reproduction in any medium, provided the original work is properly cited.
Submit your next manuscript to BioMed Central and take full advantage of:

- Convenient online submission

- Thorough peer review

- No space constraints or color figure charges

- Immediate publication on acceptance

- Inclusion in PubMed, CAS, Scopus and Google Scholar

- Research which is freely available for redistribution 